\title{
Eugenol as an efficient anesthetic for neotropical fish Prochilodus nigricans (Teleostei, Prochilodontidae)
}

[Eugenol como um anestésico eficaz para o peixe neotropical Prochilodus nigricans (Teleostei, Prochilodontidae)]

R.M. Viegas ${ }^{1}$, C.L. França ${ }^{1,4}$, J.S. Castro ${ }^{2 *}$, J.J.P. Castro ${ }^{3}$, T.C. Santana ${ }^{4}$, M.P.G. Costa-Lima ${ }^{1}$, R.N.F. Carvalho Neta $^{5}$, C.R.P. Carreiro ${ }^{1}$,E.G. Teixeira

\footnotetext{
${ }^{1}$ Laboratório de Reprodução de Organismos Aquáticos - Universidade Estadual do Maranhão - São Luís, MA

${ }^{2}$ Aluno de pós-graduação - Universidade Nilton Lins - Instituto Nacional de Pesquisas da Amazônia - Manaus, AM

${ }^{3}$ Aluno de pós-graduação - Universidade Federal de Santa Catarina - Florianópolis, SC

${ }^{4}$ Aluno de pós-graduação - Universidade Estadual do Maranhão - São Luís, MA

${ }^{5}$ Laboratório de Biomarcadores em Organismos Aquáticos - Universidade Estadual do Maranhão - São Luís, MA
}

\begin{abstract}
The use of anesthetics in fish farming is essential to reduce stress during management. The present study proposes to evaluate the effect of eugenol as an anesthetic for the management of curimatã (Prochilodus nigricans). Fifty specimens were used $(221.34 \pm 9.0 \mathrm{~g} ; 25.8 \pm 1.1 \mathrm{~cm})$, submitted to five treatments with concentrations of $0,25,50,100$ and $200 \mathrm{mgL}^{-1}$ eugenol for $10 \mathrm{~min}$. The times required to reach each anesthetic stage and the recovery of each fish were recorded. To check bloodglucose levels individual blood samples were taken from the fish before immersion and after ten minutes of anesthetic exposure. Evaluation of the anesthetic effect ongills was performed by histopathological analysis. The concentration of $50 \mathrm{mgL}^{-1}$ was within the ideal limit of three minutes recommended for surgical anesthesia induction and did not significantly increase glucose levels when compared to the control group $\left(35.7 \pm 19.4 \mathrm{mg} \mathrm{dL}^{-1}\right)$, besides not causing gill injuries. At this concentration the fish presented controlled blood glucose levels within the basal levels, besides not taking the risk to have later problems concernig mortality, because this concentration ensures the good health of the gills and good recovery of the animals.
\end{abstract}

Keywords: aquaculture, pisciculture, curimatã, recovery, anesthesia

\section{RESUMO}

O uso de anestésicos em pisciculturas é indispensável para reduzir o estresse durante o manejo. O presente trabalho propôs avaliar o efeito do eugenol como anestésico para manejo do curimatã (Prochilodus nigricans). Foram utilizados 50 espécimes (221,34 $\pm 9,0 \mathrm{~g} ; 25,8 \pm 1,1 \mathrm{~cm})$, submetidos a cinco tratamentos com concentrações de 0, 25, 50, 100 e $200 \mathrm{mg} \mathrm{L} \mathrm{L}^{-1}$ de eugenol em exposição de 10 minutos. Foram registrados os tempos necessários para atingir cada estágio anestésico e a recuperação de cada peixe. Para verificação dos níveis de glicose sanguínea, foram realizadas coletas individuais de sangue dos peixes antes da imersão e após os 10 minutos de exposição ao anestésico. A avaliação do efeito do anestésico sobre as brânquias foi realizada por meio de análises histopatológicas. A concentração de $50 \mathrm{mg} \mathrm{L}^{-1}$ ficou dentro do limite ideal de três minutos preconizado para indução à anestesia cirúrgica e não elevou

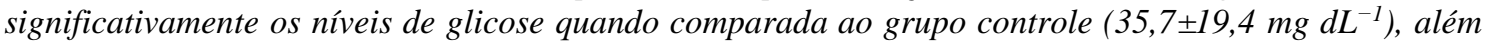
de não provocar lesões branquiais. Nessa concentração, os peixes apresentaram níveis de glicose sanguínea controlada, dentro dos teores basais, além de não correrem o risco de apresentarem problemas posteriores em relação à mortalidade, pois essa concentração garante a boa saúde das brânquias e uma boa recuperação dos animais.

Palavras-chave: aquicultura, piscicultura, curimatã, recuperação, anestesia

Recebido em 19 de fevereiro de 2020

Aceito em 11 de maio de 2020

*Autor para correspondência (corresponding author)

E-mail: jonscastroo@gmail.com 


\section{INTRODUCTION}

Routine procedures of aquaculture activity such as biometrics, hormonal applications, and transport have strong effects on physiology and can cause high levels of stress in fish, increasing susceptibility to pathogenic and infectious diseases, affecting their reproductive capacity and even death (Hurst, 2007). Thus, the use of appropriate anesthetics at effective concentrations is essential to reduce the action of stressors and minimize mortality in fish farming (Ross and Ross, 2008). Different anesthetics require different concentrations to reach the desired anesthesia stage and their efficacy has intraspecific, and interspecies variations (Teixeira et al., 2011). Therefore, the choice of anesthetic should be related to the cost, efficacy, availability and safety of fish, humans and the environment (Marking and Meyer, 1985), as well as pertinent characteristics such as rapid action in the nervous system and the sequelae after the use of these substances (Gonçalves et al., 2008).

The appropriate anesthetic at its optimal concentration should minimize negative impacts of management, reduce stress on fish, produce anesthesia less than or equal to three minutes, and recovery should occur within 5 to $10 \mathrm{~min}$ (Marking and Meyer, 1985; Ross and Ross, 2008). These characteristics include eugenol (4-allyl-2methoxyphenol), a compound derived from clove oil, viscous liquid obtained by distillation of the leaves, buds, flowers and stem of Eugenia aromatica or Eugenia caryophyllata (Mylonas et $a l ., 2005)$. Eugenol is rapidly eliminated from the bloodstream, relatively low cost, has good efficacy and is readily available in nature, and is considered safe for animals, the environment and those who handle it (Woody et al., 2002). Eugenol has been found to be an acceptable anesthetic with potential for use in aquaculture and has been widely used in several studies with different fish species (Moreira, 2009; Rotili et al., 2012), but studies to verify likely immediate effects on fish structures such as gills are incipient.

The gills are organized in a system of progressive subdivisions, giving rise to the gill slits, separated by septa with the gill arch, where the rows of gill filaments are located, whose surfaces give rise to the folds that constitute the lamellae, primary sites of gas exchange (Nogueira et al., 2008). The anesthetic solution is captured by the gills, through which the anesthetic is absorbed and eliminated (Ross and Ross, 2008), and side effects caused by anesthetics may affect gill health and endanger the survival of fish after anesthesia (Oliveira et al., 2009).

Curimatã (Prochilodus nigricans), is a freshwater fish distributed in the Amazon and Tocantins River basins (Fricke et al., 2020), due to its high consumption in Brazil it is widely cultured in fish farms in the northern and northeastern Brazil. In this way, the objective of this study was to evaluate the effect of different concentrations of eugenol as an anesthetic and to determine its ideal dose for $P$. nigricans.

\section{MATERIALS AND METHODS}

The current study was approved by the Ethics Committee on Animal Experimentation of the UEMA Veterinary Medicine course - (33/2016). This study was conducted at the Laboratory of Reproduction of Aquatic Organisms and the Laboratory of Fisheries and Aquatic Ecology (LABPEA), both of the State University of Maranhão (UEMA). Fifty specimens of $P$. nigricans with a total average length of $25.8 \pm 1.1$ $\mathrm{cm}$ were used, weighing an average of $221.34 \pm 9.0$ g. The fish were acclimated in a masonry tank and fed ad libitum twice daily with commercial feed $(28 \% \mathrm{CP})$. During this period, the water temperature was $29.47 \pm 0.30{ }^{\circ} \mathrm{C}$, oxygen dissolved at $6.15 \pm 1.12 \mathrm{mg} \mathrm{L}^{-1}$ and $\mathrm{pH} 7.35 \pm 0.22$. Feeding was stopped 24 hours before the experimental procedure.

Eugenol (Sigma $\left.{ }^{\circledR}\right)$, due to its oily nature, was diluted in ethanol PA, resulting in a stock solution at a concentration of $100 \mathrm{mg} \mathrm{mL}{ }^{-1}(1: 10)$ in accordance with Rotili et al. (2012). For exposure and recovery 80 liter capacity aquariums were used, containing 40 liters of water and provided with constant aeration. To verify the influence of anesthetic concentration on fish exposure, five treatments with eugenol concentrations of 0,25 , 50, 100 and $200 \mathrm{mg} \mathrm{L}^{-1}$ were performed. For each concentration 10 fish were individually immersed, randomly collected and exposed to anesthetic concentration for $10 \mathrm{~min}$. The different stages of anesthesia were recorded according to the criteria proposed by Ross and Ross (2008) described in Table 1. 
Table 1. Stages of anesthesia in fish*

\begin{tabular}{|c|c|c|}
\hline Stage & Description & Physiological and behavioral signs \\
\hline 0 & Normal & $\begin{array}{l}\text { Reactive to external stimuli; normal opercular beats; normal } \\
\text { muscle reaction. }\end{array}$ \\
\hline I & Light sedation & $\begin{array}{l}\text { Reactive to external stimuli, reduced movement, slower opercular } \\
\text { beats, normal balance. }\end{array}$ \\
\hline II & Deep sedation & $\begin{array}{l}\text { Total loss of reactivity to external stimuli except for strong } \\
\text { pressure; slight fall in opercular movement; normal balance. }\end{array}$ \\
\hline III & Narcosis & $\begin{array}{l}\text { Partial loss of muscle tone; erratic swimming, increased } \\
\text { opercular movements; reactive only to strong tactile stimulation } \\
\text { or vibration. }\end{array}$ \\
\hline IV & Deeper anesthesia & $\begin{array}{l}\text { Total loss of muscle tone; total loss of balance; slow but regular } \\
\text { opercular beat. }\end{array}$ \\
\hline $\mathrm{V}$ & Surgical anesthesia & $\begin{array}{l}\text { Total loss of reaction to even massive stimulation; slow and } \\
\text { irregular opercular movements; slow heartbeat; total loss of all } \\
\text { reflexes. }\end{array}$ \\
\hline
\end{tabular}

*Modified from Ross and Ross (2008).

The time required to reach each anesthetic stage was measured by a digital stopwatch and after ten minutes of exposure the fish were removed for biometrics and then transferred to the recovery aquarium, where the time to reach their normal balance was recorded. Active swimming was measured. To check bloodglucose levels, individual blood samples were taken from fish before immersion and after ten minutes of exposure. With the aid of a heparinized $1 \mathrm{ml}$ syringe, blood was collected by caudal puncture and immediately after collection the blood glucose content was checked with the aid of a digital glucometer (OneTouch Ultra®).

The anesthetic effect on the gills of $P$. nigricans was evaluated by histological analysis. After anesthetic recovery, the fish were euthanized by the medullary section and the first gill arch of each specimen was removed and fixed in $10 \%$ formaldehyde and kept in 70\% alcohol until the usual histological technique was applied. The first gill arch was dehydrated in increasing series of alcohols, diaphanized in xylol, impregnated and embedded in paraffin (Velloso et al., 2012). Cross sections of approximately $5 \mu \mathrm{m}$ thickness were stained with Hematoxylin and Eosin (HE). The slides were read by a light microscope using 10x, $40 \mathrm{x}$ objectives and the lesions found were photomicrographed in AXIOSKOP - ZEIS photomicroscope. The classification of gill alterations according to the lesion importance factor was made according to a scale of Bernet $e t$ al. (1999) in: I (minimal pathological importance), II (moderate pathological importance), and III (marked pathological importance).

The data were analyzed by one-way analysis of variance. When the $F$ value indicated significant differences $(\mathrm{P}<0.05)$, the means were compared by the Tukey test. The results are presented as mean \pm standard deviation, all analyses were performed by Bioestat software, version 5.0.

\section{RESULTS AND DISCUSSION}

The specimens of $P$. nigricans isolated from different anesthetics of eugenol have indicative sizes of adult fish, including average amplitude data of the first sexual maturation of species recorded by Mota and Rufino (1997). The individuals showed no significant difference in the total weight and total length $(\mathrm{P}>0.05)$ (Table 2 ), and the fish demonstrated healthy external exposure during anesthesia, manipulation procedures, and $24 \mathrm{~h}$ after exposure, with no mortality.

In culture systems, the use of anesthetic is essential during management procedures, however, for the ideal use of this anesthetic, it is necessary to understand the dose required for a given size of fish, since different size fish respond differently to the anesthesia time when submitted to the same anesthetic concentrations (Roubach $e t$ al., 2005), in addition, the ideal use of the anesthetic avoids mortality and minimizes management costs. Juvenile fish can be anesthetized at lower concentrations than adults of the same species, as they have comparatively 
smaller branchial surfaces, capable of better absorbing the anesthetic (Roubach et al., 2005). This statement corroborates the study by Souza et al. (2015) who, when evaluating the effect of eugenol on Lutjanus synagris, observed that the larger the individual, the more resistant to sedation with this anesthetic.

In our study, $P$. nigricans did not undergo the stage of mild sedation in any of the treatments. On the other hand, higher concentrations of eugenol
(100 $\mathrm{mg} \mathrm{L}^{-1}$ and $200 \mathrm{mg} \mathrm{L}^{-1}$ ) triggered a series of behaviors in P. nigricans, such as hyperactivity, cough, and regurgitation. These behaviors probably contributed to accelerating the opercular beat of this species, with a consequent increase in the flow of water over the gills, contributing to faster anesthesia. When exposed to a lower concentration of eugenol $\left(50 \mathrm{mg} \mathrm{L}^{-1}\right), P$. nigricans immediately reduced their opercular beats, causing longer anesthesia compared to other concentrations (Table 3).

Table 2. Biometric data of Prochilodus nigricans anesthetized with different concentrations of eugenol

\begin{tabular}{ccc}
\hline Concentration $\left(\mathrm{mg} \mathrm{L}^{-1}\right)$ & WT $(\mathrm{g})$ & LT $(\mathrm{cm})$ \\
\hline 0 & $220.8 \pm 36.3^{\mathrm{a}}$ & $27.1 \pm 3.2^{\mathrm{a}}$ \\
25 & $207.5 \pm 51.9^{\mathrm{a}}$ & $26.3 \pm 3.1^{\mathrm{a}}$ \\
50 & $232.5 \pm 48.0^{\mathrm{a}}$ & $24.0 \pm 1.2^{\mathrm{a}}$ \\
100 & $221.7 \pm 39.6^{\mathrm{a}}$ & $25.7 \pm 1.5^{\mathrm{a}}$ \\
200 & $224.2 \pm 65.6^{\mathrm{a}}$ & $25.8 \pm 2.8^{\mathrm{a}}$ \\
\hline
\end{tabular}

Where: $\mathrm{WT}=$ total weight of the individual; $\mathrm{LT}=$ total length of the individual. Data presented by means and standard deviation.

Table 3. Stages of behavior (in seconds) of Prochilodus nigricans adults exposed to different concentrations of eugenol

\begin{tabular}{cccccc}
\hline $\begin{array}{c}\text { Dose } \\
\left(\mathrm{mg} \mathrm{L}^{-1}\right)\end{array}$ & Stage II & Stage III & Stage IV & Stage V & Recovery \\
\hline 25 & $16.3 \pm 3.9^{\mathrm{a}}$ & $26.7 \pm 4.9^{\mathrm{a}}$ & $38.6 \pm 5.0^{\mathrm{a}}$ & $77.2 \pm 13.5^{\mathrm{a}}$ & $148.67 \pm 15.0^{\mathrm{a}}$ \\
50 & $29.3 \pm 8.2^{\mathrm{b}}$ & $44.2 \pm 9.5^{\mathrm{b}}$ & $61.8 \pm 9.3^{\mathrm{b}}$ & $162.8 \pm 30.2^{\mathrm{b}}$ & $398.3 \pm 41.4^{\mathrm{b}}$ \\
100 & $12.5 \pm 2.3^{\mathrm{a}}$ & $17.7 \pm 3.5^{\mathrm{a}}$ & $23.8 \pm 4.0^{\mathrm{c}}$ & $30.2 \pm 3.4^{\mathrm{c}}$ & $687.0 \pm 134.9^{\mathrm{c}}$ \\
200 & $13.3 \pm 3.6^{\mathrm{a}}$ & $23.7 \pm 7.4^{\mathrm{a}}$ & $34.5 \pm 9.4^{\mathrm{ac}}$ & $51.4 \pm 20.0^{\mathrm{a}}$ & $1032.1 \pm 115.4^{\mathrm{d}}$ \\
\hline
\end{tabular}

Where: Stage II - deep sedation; stage IIInarcosis; stage IV - deep anesthesia; stage Vsurgical anesthesia. Lower case letters indicate difference between treatments $(\mathrm{P}<0.05)$. There was no gradual increase in the behavior of $P$. nigricans exposed to different concentrations of eugenol, where the animals went from the normal stage to deep sedation (stage II). We can deduce that even in low concentrations, this anesthetic has a faster effect on physiology, affecting behaviors and accelerating the stages of anesthesia in this species. Our results corroborate with Vidal et al. (2008) when observing that Oreochromis niloticus exposed to concentrations of 200 and $250 \mathrm{mg} \mathrm{L}^{-1}$ of eugenol, did not show an evident progressive transition from the behaviors characteristic of the initial stages of anesthesia to the deeper stages, due to the speed of action of eugenol in the body.

The lowest concentration $\left(25 \mathrm{mg} \mathrm{L}^{-1}\right)$ evaluated in this experiment presented induction times similar to the highest concentrations, not differing from the concentration of $200 \mathrm{mg} \mathrm{L}^{-1}$ in the different stages of anesthesia ( $\mathrm{P}>0.05)$, however, it was significantly less than the time to induce the concentration of $50 \mathrm{mg} \mathrm{L}^{-1}$ in the different stages $(\mathrm{P}<0.05)$. When submitted to the lowest concentrations, $P$. nigricans maintained its normal behavior regarding the opercular beat, not decreasing as in the concentration of $50 \mathrm{mg} \mathrm{L}^{-1}$. This behavior probably contributed to greater absorption of the anesthetic over time, reaching levels of deep anesthesia similar to the higher concentrations.

The exposure of $P$. nigricans to $50 \mathrm{mg} \mathrm{L}^{-1}$ of eugenol revealed an average time of induction at all stages of anesthesia, being higher than the other treatments $(\mathrm{P}<0.05)$. For deep anesthesia induction, the meantime was $61.8 \pm 9.3 \mathrm{~s}$. Results found by Park et al. (2008) when evaluating a similar eugenol concentration in Epinephelus bruneus, recorded an average induction time of $66 s$, staying within the ideal limit of three minutes 
for surgical anesthesia induction, recommended by Marking and Meyer (1985).

The concentrations of $100 \mathrm{mg} \mathrm{L}^{-1}$ and $200 \mathrm{mg} \mathrm{L}^{-1}$ of eugenol accelerated the sedative effect on the animals, evidenced by hyperactivity and irritation behaviors, confirmed by the rapid movement and coughing behavior, with regurgitation reflex. Hyperactivity and irritation behavior were also observed by Vidal et al. (2007) for juveniles of Brycon cephalus and Colossoma macropomum and for other fish species. According to Mylonas et al. (2005) this reaction is caused by the anesthetic and not by the alcohol used during the preparation of the solution, as Sparus aurata and Dicentrarchus labrax, exposed separately to alcohol did not show euphoria or irritation behaviors, when compared with the presence of eugenol (Collins, 1985).

In culture systems, the deep anesthesia stage is recommended for biometrics and quick handling, as it causes the total loss of balance of the fish, allowing activities to be carried out safely, reducing stress, and minimizing mortality risks (Simões and Gomes, 2009). Although the total time for fish recovery is less important in a field situation, a quick and complete resumption of normal physiological activities is recommended as soon as possible (Walsh and Pease, 2002).

In this study, we observed that the recovery time of $P$. nigricans had a progressive increase with the increase in eugenol concentrations $(\mathrm{P}<0.05)$. Considering the importance of the recovery time for safe use in management, we suggest concentrations of $25 \mathrm{mg} \mathrm{L}^{-1}$ and $50 \mathrm{mg} \mathrm{L}^{-1}$ of eugenol for $P$. nigricans. The recovery times in these treatments were within the maximum limit considered safe by Ross and Ross (2008). Concentrations of $100 \mathrm{mg} \mathrm{L}^{-1}$ and $200 \mathrm{mg} \mathrm{L}^{-1}$, on the other hand, showed an average recovery time above 10 minutes, therefore, above the recommended time for fish safety. According to Park et al. (2008), the optimal concentration of anesthetic should minimize the negative impacts of management, reduce stress on fish, produce anesthesia in a period of less than or equal to $3 \mathrm{~min}$ and allow recovery within a maximum period of $10 \mathrm{~min}$.

The $P$. nigricans specimens had an average blood glucose value of $21.8 \pm 8.7 \mathrm{mg} \mathrm{L}^{-1}$, before exposure to the anesthetic (control). Exposure to concentrations of $25 \mathrm{mg} \mathrm{L}^{-1}$ and $50 \mathrm{mg} \mathrm{L}^{-1}$ did not significantly increase glucose levels when compared to the control group, with values of $39.7 \pm 21.4 \mathrm{mg} \mathrm{L}^{-1}$ and $35.7 \pm 19,4 \mathrm{mg} \mathrm{L}^{-1}$, respectively (Figure 1), indicating that adult $P$. nigricans can be exposed to these concentrations without additional stress. On the other hand, 100 $\mathrm{mg} \mathrm{L}^{-1}$ and $200 \mathrm{mg} \mathrm{L}^{-1}$ of eugenol significantly increased the blood glucose levels of these animals compared to the control group (Figure 1) $(\mathrm{P}<0.05)$, indicating a higher level of stress in these concentrations .

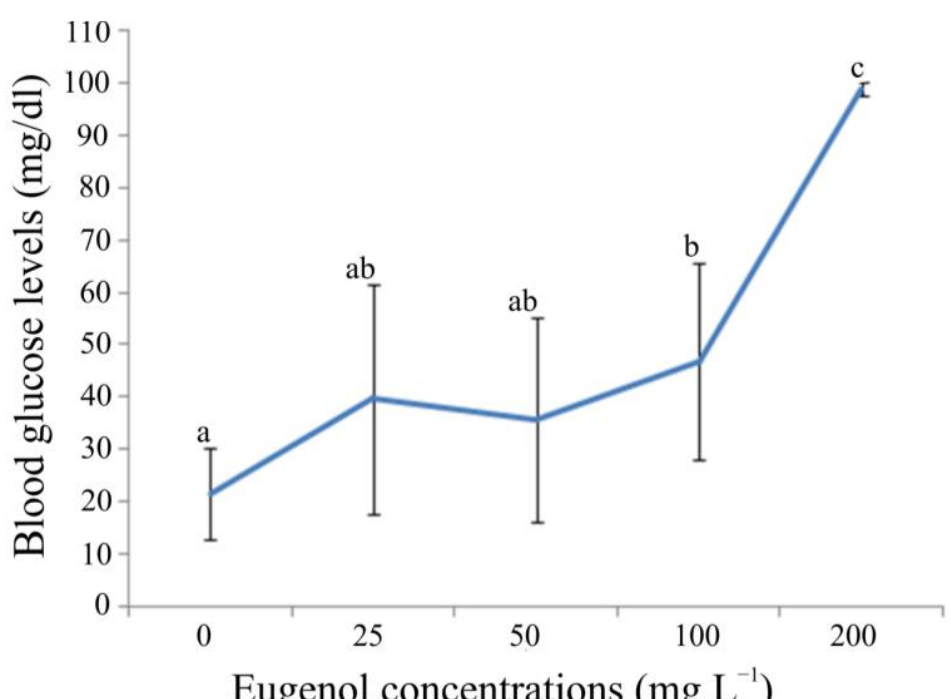

Figure 1. Bloodglucose levels of Prochilodus nigricans exposed to different concentrations of eugenol. Lower case letters indicate difference between treatments $(\mathrm{P}<0.05)$. 
Studies that aim to evaluate the physiological stress of fish submitted to anesthetics through analysis of cortisol and glucose are important since these physiological effects vary between species, stage of development, and metabolic state of the animal (Moreira 2009). A study reveals that fish exposed to anesthetics generally increase levels of cortisol and blood glucose in response to the stress of this solution (Mommesen et al., 1999).

In addition to the possible effects on the physiology of fish, eugenol can also cause undesirable reactions in the morphology of some tissues. The gills are a multifunctional organ, which is directly exposed to the actions of the anesthetic in the environment through absorption and transport. According to Santana et al. (2016), concentrations of anesthetics outside the ideal limit for a given species can cause mild, moderate, and severe histological changes. In our experiment, we observed that fish submitted to concentrations of $0 \mathrm{mg} \mathrm{L}^{-1}$ (control group), $50 \mathrm{mg}$ $\mathrm{L}^{-1}$ and $200 \mathrm{mg} \mathrm{L}^{-1}$ of eugenol did not show branchial lesions. Fish exposed to concentrations of $25 \mathrm{mg} \mathrm{L}^{-1}$ and $100 \mathrm{mg} \mathrm{L}^{-1}$ showed the following changes: disorganization of the lamellae, partial fusion of the lamellae, congestion and aneurysms (Figure2).

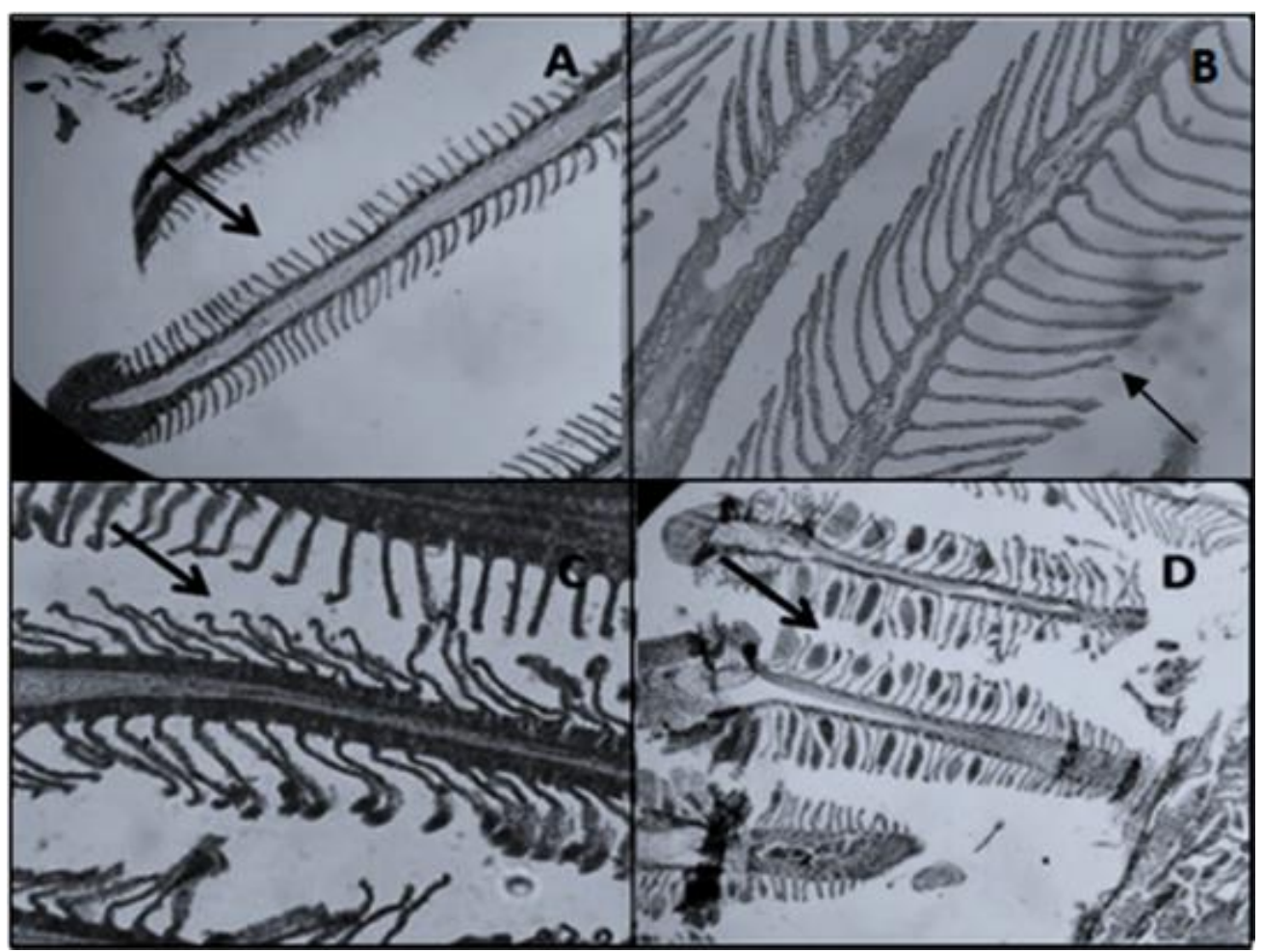

Figure 2. Histology of the gills of Prochilodus nigricans exposed to different eugenol concentrations. (A and B) arrow indicating lamellae with normal characteristics (50 $\mathrm{mg} \mathrm{L}^{-1}$ and $\left.200 \mathrm{mg} \mathrm{L}^{-1}\right)$; (C) arrow indicating disorganization in the lamellae $\left(100 \mathrm{mg} \mathrm{L}^{-1}\right)$; (D) arrow indicating congestion $\left(25 \mathrm{mg} \mathrm{L}^{-1}\right)$.

In the present study, the damage caused to the gills of $P$. nigricans at concentrations of $25 \mathrm{mg} \mathrm{L}^{-1}$ and $100 \mathrm{mg} \mathrm{L}^{-1}$ may be related to the individual's behavior in relation to treatment, since fish exposed to $25 \mathrm{mg} \mathrm{L}^{-1}$ maintained the normal opercular rhythm contributing to a greater exchange of water by the gills for a long time, increasing the substance's absorption in this tissue. These lesions are evaluated as circulatory disorders, being considered as mild damage, and can be reversible when the animal is directed to a controlled environment (Bernet et al., 1999).

The branchial epithelium represents a surface in continuous contact with the environment, thus being an important target of pollutants or substances that are present in the water (Wong and Wong, 2000). In general, lifting of the epithelium 
and circulatory disorders (such as aneurysms) in fish gills can indicate acute toxicity, where contact with the toxic agent, in an approximate period of 24 hours, can accumulate in the tissue and its effects appear immediately or over a few days (Vanderoost et al., 2003).

\section{CONCLUSIONS}

The appropriate concentration of eugenol anesthetic for rapid management of adult Prochilodus nigricans is $50 \mathrm{mg} \mathrm{L}^{-1}$. At this concentration the fish will have their blood glucose levels controlled within the basal levels and will not run the risk of further mortality problems, as the anesthetic at this concentration ensures good gill health and good animal recovery.

\section{ACKNOWLEDGEMENTS}

We would like to acknowledge the Maranhão State Foundation for Research and Scientific and Technological Development (FAPEMA) and the Brazilian National Research Council (CNPq) for granting scholarships. We also thank ALCON PET ${ }^{\circledR}$ for supplying the necessary inputs for the research.

\section{REFERENCES}

BERNET, D.; SCHIMIDT, H.; MEIER, W. et al. Histopatology in fish: proposal for a protocol to assess aquatic pollution. J. Fish Dis., v.22, p.2534, 1999.

COLlins, V.J. Princípios de anestesiologia. 2.ed. Rio de Janeiro: Guanabara Koogan, 1985. $1025 \mathrm{p}$.

FRICKE, R.; ESCHMEYER, W.N.; VAN DER LAAN, R. (Eds.). Eschmeyer's Catalog of Fishes: genera, Species, References. California, 2020. Available

in:

http://researcharchive.calacademy.org/research/ic hthyology/catalog/fishcatmain.as. Accessed in: 23 Apr. 2020.

GONÇALVES, A.F.N.; SANTOS, E.C.C.S.; FERNANDES, J.B.K. Mentol e eugenol como substitutos da benzocaína na indução anestésica de juvenis de pacu. Acta Sci. Anim. Sci., v.30, p.339-344, 2008.
HURST, T.P. Causes and consequences of winter mortality in fishes. J. Fish Biol., v.71, p.315-345, 2007.

MARKING, L.L.; MEYER, F.P. Are better fish anesthetics needed in fisheries. Fisheries, v.10, p.2-5, 1985.

MOMMSEN, T.P.; VIJAYAN, M.M.; MOON, T.W. Cortisol in teleost: dynamics, mechanism of action, and metabolic regulation. Rev. Fish Biol. Fish, v.9, p.211-268, 1999.

MOREIRA, A.G.L. A eficácia do eugenol e do mentol como anestésicos em tilápia do nilo (Oreochromis niloticus). 2009. 56f. Trabalho de Conclusão de Curso (Graduação em Engenharia de Pesca), Universidade Federal do Ceará, Fortaleza.

MOTA, S.A.; RUFFINO, M.L. Biologia e pesca do curimatá (Prochilodus nigricans agassiz, 1829) (Prochilodontidae) no médio Amazonas. Rev. UNIMAR, v.19, p.493-508, 1997.

MYLONAS, C.C.; CARDINALETTI, G.; SIGELAKI, I. et al. A Comparative efficacy of clove oil and 2-phenoxyethanol as anesthetics in the aquaculture of European sea bass (Dicentrarchus labrax) andgilthead sea bream (Sparus aurata) at different temperatures. Aquaculture, v.246, p.467-481, 2005.

NOGUEIRA, D.J.; CASTRO, S.C.; SÁ, O.R. Avaliação da qualidade da água no reservatório UHE Furnas - MG, utilizando as brânquias de Pimelodus maculatus (LACÈPÉDE, 1803) como biomarcador de poluição ambiental. Ciênc. Praxis, v.1, p.15-20, 2008.

OLIVEIRA, R.A.D.; REIS, T.V.; SACRAMENTO, C.K.D. et al. Volatile chemical constituents of rich spices in eugenol. Rev. Bras. Farmacogn., v.19, p.771-775, 2009.

PARK, M.O.; HUR, J.W.; IM, S.Y. et al. Anaesthetic efficacy and physiological responses to clove oil-anaesthetized kelpgrouper Epinephelus bruneus, Aquac. Res., v.39, n.8, p.877-884, 2008.

ROSS, L.G.; ROSS, B. Anesthetic and sedative techniques for aquatic animals. 3.ed. Oxford: Blackwell Science, 2008. 240p.

ROTILI, D.A.; DEVENS, M.A.; DIEMER, O. et al. Uso de eugenol como anestésico em pacu. Pesqui. Agropecu. Trop., v.42, p.288-294, 2012. 
ROUBACH, R.; GOMES, L.C.; LEÃO FONSECA, F.A.; VAL, A.L. Eugenol as an efficacious anesthetic for tambaqui, Colossoma macropomum (Cuvier). Aquac. Res., v.36, p.1056-1061, 2005.

SANTANA, M.; BORGES, L.M.; CAVALCANTE, R.M. Transformações metabólicas de agrotóxicos em peixes: uma revisão. Orbital: Electron. J. Chem., v.8, p.257268, 2016.

SIMÕES, L.N.; GOMES, L.C. Eficácia do mentol como anestésico para juvenis de tilápia-do-nilo (Oreochromics niloticus). Arq. Bras. Med. Vet. Zootec., v.61, p.613-620, 2009.

SOUZA, R.L.M.; VETTORAZZI, M.B.; KOBAYASHI, R.K.; NETO, M.A.A.F. Eugenol as an anaesthetic in the management of farmed lane snapper, Lutjanus synagris (Linnaeus, 1758). Rev. Cienc. Agronom., v.46, p.532-538, 2015.

TEIXEIRA, E.G.; MOREIRA, A.G.L.; MOREIRA, R.L.; SANTOS LIMA, F.R. Mentol como anestésico para diferentes classes de tamanho de tilápia do Nilo. Arch. Vet. Sci., v.16, p.75-83, 2011.

VANDEROOST, R.; BEYER, J.; VERMEULEN, N.P. Fish bioaccumulation and biomarkers in environmental risk assessment: a review. Environ. Toxicol. Pharmacol., v.13, p.57-149, 2003.
VELLOSO, A.L.; MATTOS ALMEIDA, F.; COUSIN, J.C.B.; PEREIRA, J. Histopatologia de brânquias de Paralichthys orbignyanus (Teleostei: paralichthyidae) parasitado por Therodamas fluviatilis (Copepoda: ergasilidae). Atlântica, v.34, p.47-52, 2012.

VIDAL, L.V.O.; ALBINATI, R.C.B.; SANTOS NETO, E.B. et al.Influência do peso de juvenis de matrinxã (Brycon cephalus) e tambaqui (Colossoma macropomum) à ação anestésica do eugenol. Rev. Bras. Saúde Prod. Anim., v.8, p.212-216, 2007.

VIDAL, L.V.O; ALBINATI, R.C.B.; ALBINATI, A.C.L. et al. Eugenol as an anesthetic for Nile tilapia. Pesqui. Agropecu. Bras., v.43, p.1069-1074, 2008.

WALSH, C.T.; PEASE, B.C. The use ofcloveoil as ananaesthetic for thelongfinnedeel, Anguilla reinhardtii (Steindachner). Aquacult. Res., v.33, p.627-635, 2002.

WONG, C.K.; WONG, M.H. Morphological and biochemical changes in thegills of tilapia (Oreochromis mossambicus) to ambient cadmium exposure. Aquat. Toxicol., v.48, p.517-527, 2000.

WOODY, C.A.; NELSON, J.; RAMSTAD, K. Clove oil as an anaesthetic for adult sockeye salmon: field trials. J. Fish Biol., v.60, p.340-347, 2002. 